\title{
Learning Style Preferred by English and Computer Students in Indonesia Context
}

\author{
https://doi.org/10.3991/ijet.v14.i10.9997 \\ Dyah Sunggingwati ( $\bowtie)$, Haviluddin \\ Universitas Mulawarman, Samarinda, Indonesia \\ sunggingwati@gmail.com
}

\begin{abstract}
This study investigates students' learning style at tertiary level in Indonesia context. Eighty students of English Education and Computer Science Department participated in this study. Using a case study design, Kolb Learning Style Inventory and interview were employed to gather the data. The results showed that the students had similar learning style. They employed more Diverger style than three other characteristics. They had more ability in Concrete Experience in grasping experience process and Reflective Observation was dominant in transforming experience process. This indicated that the English students were likely to observe, do and feel while the Computer students had more mixed style; feel, observe, and think and do. These findings will contribute to our knowledge what types of activities and teaching methods will suit with the students' learning styles.
\end{abstract}

Keywords - Student learning style; computer students; English students

\section{Introduction}

In the globalization era, technology insert in daily life is undeniable is which new tools and information can go across nation, social and economic practice. This is robust intention that there needs skills and competencies required that allow people to involve in this globalization era, therefore what is often called as the 21st century skills should be anticipated. In education, these skills should be occupied and progressively developed as students need to prepare for their future.

At tertiary level, lecturers employ many teaching techniques and methodologies in their classes to allow their students understand the material given. One important feature should be recognized before teaching technique and methodology implementation is knowing learning style of the students. Recognizing and updating the knowledge about this will provide understanding the lecturers to suit their teaching strategies to suit with their student learning styles.

Oxford (2003) has defined learning styles as general approaches that learners utilize in acquiring a new language or in learning other subjects. These styles are the overall patterns that give learning behavior a general direction. By understanding one's learning style, one will be able to develop the skills that help one learns in a variety of ways to achieve full potential. Further, this understanding will assist teach- 
ers to enable them to match their teaching styles, methodologies and course organization with learners' learning styles to help learners improve their learning (Burns and Danyluk, 2017; Cornett, 1983; Sato \& Laughlin, 2018).

One of the most famous researchers in learning style is David A. Kolb with the theory of Experiential Learning since 1971. The theory informs that the learning style consists of four major styles; Diverger, Assimilator, Converger, and Accommodator. Diverger is the learning style that has a combination of Concrete Experience and Reflective Observation ability. Assimilator is the combination of Abstract Conceptualization and Reflective Observation. Converger is the combination of Abstract Conceptualization and Active Experimentation. Accommodator is the combination of Concrete Experience and Active Experimentation. Until now, Kolb's theory is widely used by many researchers as a reference (Ayidin, 2016; Burns and Danyluk, 2017; D’Amore, 2012; Eskişehir \& Bouvet, 2016; Parnrod, Darasawang \& Singhasiri, 2014; Sato \& Laughlin, 2018).

To assess individual learning style, Kolb developed a simple self-description test, called the Learning Style Inventory (LSI) which has been broadly used and accepted in management and education (Barmeyer, 2004). The inventory is short questionnaire, which evaluates the way people deal with new ideas and day-to-day situations. It contains 12 items which have four statements in each item that indicated the learning style of the students.

This study investigates learning style of the students at tertiary level from different majors; English education and computer. The results of this study is expected to contribute to the development of anticipated learning style of the students that should be accordingly adjusted with the context so that the expected learning outcome in terms of the students' achievement can be maximally obtained. In order to guide this study, the formulated research question is "What are the preferred learning styles in Kolb's Experiential Learning theory of the English Education and Computer students of Mulawarman University Samarinda?"

\subsection{Experiential learning of kolb's model}

Kolb's model of Experiential Learning by David A. Kolb in 1971 is one of the most widely used model of learning style. Experiential Learning theory believes that learning is a holistic process between experience, cognitive, and behaviour. All elements in learning is integrated and correlated each other.

Kolb (1984) explained that the Experiential Learning theory is characterized by some features of perceived learning. Learning focuses on the process and not the outcomes since ideas are formed and reformed through experience. It is a continuous process grounded in experience that the process of learning requires the resolution of conflicts between dialectically opposed modes of adaptation to the world. The dialectically opposed modes are grasping and transforming experience process. Further, Kolb underlined that learning is a holistic process of adaptation to the world that involved an integrated functioning of experience, behaviour, and cognitive. The learning involves transactions between person and environment of the real word to create 
knowledge. Kolb concluded that learning is the process whereby knowledge is created through the grasping and transforming the experience process.

\subsection{Concept of kolb's learning ability}

Experiential Learning theory by Kolb underlined that there were dialectically opposed processes in learning, which are grasping and transforming experience. Concrete Experience and Abstract Conceptualization are learning abilities in grasping experience process. On the other hand, in transforming experience process, there are also two learning abilities, which are Reflective Observation and Active Experimentation.

Concrete Experience is the ability to use feeling and hunch, to be energetic and enthusiastic, to be open minded and spontaneous, to accept people and situations the way they are, to learn from own experiences, and to be receptive and objective. Next, Abstract Conceptualization is the ability to think and act logically, to reason things out, to analyze things and break them into parts, to work with rational theories, to learn from own general conclusions, and to create concept. Reflective Observation indicates the ability to watch situations, to have a lot of questions about new things, to be quiet and reserved, to look at all sides of issues, to be careful and alert, to learn by contemplation, and to observe things. Active Experimentation is the ability to do and try things out, to be hard worker and get things done, to be responsible about things, to learn by action or practice, and to make decision and solve problem quickly.

Further, Kolb emphasized that the learning abilities are related each other. At the beginning of learning, someone will use Concrete Experience ability, where he or she generates ideas with open-minded, receptive, and objective. Then he or she will use Reflective Observation ability, where the experience is reflected, analyzed, and observed from many points of view. After that, Abstract Conceptualization ability will be used, where he or she creates concepts that integrate observations into logically sound theories. Finally, he or she will use Active Experimentation ability, where the theories will be used to make decisions and solve problems.

Learning will be very effective if people can use four abilities above very well. Unfortunately, people only tend to use two learning abilities in the early stage of growth and development. At the beginning of learning, people tend to always use one of abilities in grasping experience process, whether by Concrete Experience or Abstract Conceptualization. Then also only one in transforming experience process, whether by Reflective Observation or Active Experimentation. This kind of process makes people only rely on one learning style.

\subsection{Learning style}

Oxford (2003) points out that learning styles are general approaches that learners utilize in acquiring a new language or in learning any other subjects. These styles are the overall patterns that give learning behavior a general direction (Cornett, 1983). By understanding one's learning style, one will be able to develop the skills that help one learns in a variety of ways to achieve full potential. This understanding is also helpful 
for teachers because it enables them to match their teaching styles, methodologies and course organization with learners' learning styles to help learners improve their learning (Biadabadi, 2010). Therefore, learning style has an important role in learning. Lecturers who are able to prepare the appropriate material, teaching technique, and methodology in the class can help the improvement of the students. The students who got good treatments which suit with their learning styles can increase their academic achievement as well.

According to Kolb (2005), the Experiential Learning Theory, learning style is a combination of one learning ability in grasping experience process, whether Concrete Experience or Abstract Conceptualization, and one learning ability in transforming experience process, whether Reflective Observation or Active Experimentation. There are four learning styles in Experiential Learning Theory, which are Diverger, Assimilator, Converger, and Accommodator, Figure 1.

One with Diverger style has Concrete Experience and Reflective Observation as dominant learning abilities. People with this learning style are best at viewing concrete situations from many different points of view. A person with this style can perform better in situations that need for generation of ideas, such as a brainstorming session, has broad cultural interests and likes to gather information. They are interested in people, tend to be imaginative, and emotional. In formal learning situations, people with the Diverger style prefers to work in groups, listening with an open mind to different points of view and receiving personalized feedback.

Assimilator style has Abstract Conceptualization and Reflective Observation as dominant learning abilities. People with this learning style are best at understanding a wide range of information and putting it into short, logical form; less focused on people and more interested in ideas and abstract concepts. Generally, people with this style find it more important that a theory have logical soundness than practical value. In formal learning situations, people with this style prefer readings, lectures, exploring analytical models, and having time to think things through.

Converger style has Abstract Conceptualization and Active Experimentation as dominant learning abilities. People with this learning style are best at finding practical uses for ideas and theories. They have the ability to solve problems and make decisions based on finding solutions to questions or problems. Individuals with a Converger learning style prefer to deal with technical tasks and problems rather than with social issues and interpersonal issues. In formal learning situations, people with this style prefer to do experiment with new ideas, simulations, laboratory assignments, and practical applications.

An individual with Accommodator style has Concrete Experience and Active Experimentation as dominant learning abilities. People with this learning style have the ability to learn from primarily "hands-on" experience. They enjoy carrying out plans and involving themselves in new and challenging experiences. Their tendency may be to act on "gut" feelings rather than on logical analysis. In solving problems, individuals with an Accommodator learning style rely more heavily on people for information than on their own technical analysis. In formal learning situations, people with the Accommodator learning style prefers to work with others to get assignments done, to 
set goals, to do field work, and to test out different approaches to completing a project.

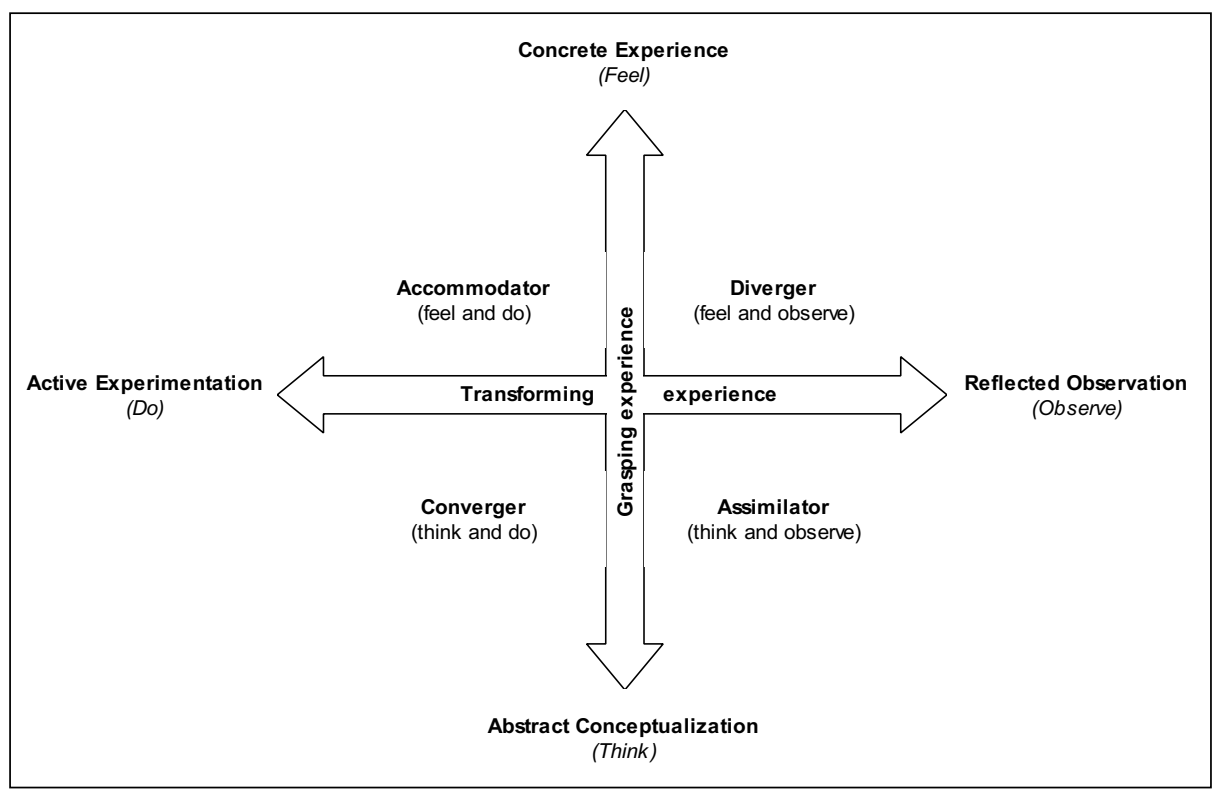

Fig. 1. Kolb's Learning Abilities and Styles Diagram

\subsection{Learning style inventory}

There are numerous models in literature about learning styles such as MyersBriggs (1940), Dunn \& Dunn (1978), Kolb (1984) and Felder \& Silverman (1988). Each of these models have specific rules in order to classify students' styles of learning (Alzain, Clark, Jwaid, \& Ireson, 2018; Dunn, 1990; Felder \& Silverman, 1988; Malcik \& Miklosikova, 2017; Mouzouri, 2016; Partridge, 1983). In this study, Kolb theory have been implemented as a model for learning style.

Kolb (2005) asserted that the Learning Style Inventory (LSI) is an instrument designed to measure the degree to which individuals display different learning abilities and styles. It contains 12 items that ask the respondents to rank four statements that correspond to the four learning abilities, which are Concrete Experience, Reflective Observation, Abstract Conceptualization and Active Experimentation. The total higher scores of the learning abilities represented one's learning style; whether Diverger (high Concrete Experience and Reflective Observation), Assimilator (high Abstract Conceptualization and Reflective Observation), Converger (high Abstract Conceptualization and Active Experimentation) or Accommodator (high Concrete Experience and Active Experimentation). 


\subsection{Previous research}

Studies on experiential learning have been investigated in different fields and school levels. For example, at tertiary level. Burns and Danyluk (2017) reported their preliminary case study investigation of two preservice teachers during their nontraditional practicum. Data gathered from portfolios, promotional materials, and interviews were analyzed using the framework of Kolb's experiential learning model. The result indicated that the practicum environment has challenged their conceptual learning and teaching perspectives. They became aware the importance of students own learning style.

Vural (2016) investigated the relationship between the Learning styles of 211 teacher candidates and those of their parents in a Turkish university. Using GrashaRiechmann Student Learning Style Inventory and Kolb Learning Style Inventory, the findings indicated that that there is no relation between the learning styles of teacher candidates and those of their parents using Kolb Learning Style Inventory. However, there is a medium level relationship between the teacher candidates' learning styles and that of their parents.

Parnrod, Darasawang and Singhasiri (2014) searched qualitatively for the relationship among cognitive styles, learning strategies and task with four engineering students. Using Kolb questionnaires (2005), it was found that the three factors are interrelated, diverger' and 'assimilator' are the dominant styles in their cognitive style investigation. The students learning strategies was influenced by their level of proficiency. However, since there were very limited participants in this study therefore the conclusion needed to be validated with more learners involved in the future research.

Eskişehir and Bouvet (2016) investigated the correlation between reading comprehension and learning styles and reading strategies among 91 students studying French at an Australian and a Turkish university. Using the Survey of Reading Strategies, the Kolb Learning Style Inventory 3.1 and reading comprehension test, the results indicated that that there was a small negative correlation between perceived use of reading strategies and reading comprehension for all participants and, in particular, for the Australian subgroup; however, correlation coefficients were not statistically significant. Furthermore, the findings showed that converging styles was the highest usage and assimilating styles were the lowest in both subgroups. Learners with converging styles preferred to transform information through active experimentation, while those with assimilating styles transformed information through reflective observation. They hypothesized that the converging styles got highest frequency used due to the participant's keen on learning by doing.

Ayidin (2016) conducted research to determine eighth grade students' learning styles and attitudes toward math class and to show the relationship between their learning styles and attitudes toward math class of 100 eight graders in Central Anatolia in Turkey. The samples were randomly selected. Using Kolb Learning Style Inventory developed by Kolb (1985) and Attitude Scale toward Math Class, the results showed that there was a correlation between attitude level to math lesson learning style. Further, the students applied mostly assimilating learning style and the least of accommodating style. 
At tertiary level, Parnrod, Darasawang and Singhasiri (2014) searched qualitatively for the relationship among cognitive styles, learning strategies and task with 778 engineering students. Using Kolb questionnaires (2005), it was found that the three factors are interrelated, diverger' and 'assimilator' are the dominant styles in their cognitive style investigation. The students learning strategies was influenced by their level of proficiency. However, since there were very limited participants in this study therefore the conclusion needed to be validated with more learners involved in the future research.

Kolb Learning Style Inventory was also implemented to undergraduate nursing and midwifery students by D'Amore (2012). The study tried to find out whether these learning styles were influenced by student demographic characteristics. A questionnaire was distributed to first-year Bachelor of Nursing, Bachelor of Midwifery and Bachelor of Arts students at a metropolitan (Melbourne) and rural (Ballarat) campus of Australian Catholic University. The questionnaire was administered in 2008, at the end of the first tutorial of second semester to potentially 443 students. The questionnaire included a list of demographic questions and also contained Kolb Learning Style Inventory. It was a 12-item questionnaire; each item had a statement with the option of four different endings. These four different endings were ranked by participants to reveal their information processing style of learning. The majority of respondents were female (N90\%) and $\sim 83 \%$ were between the ages of $18-25$. Almost $85 \%$ of respondents were from an English-speaking background and $\sim 38 \%$ were mature age students (i.e. not school-leavers). Most respondents were Australian citizens/permanent residents $(\sim 88 \%)$. More than $26 \%$ of students were from a rural residential background. The highest level of previous education for most respondents was Year 12/ equivalent level (68.7\%). The overall Concrete Experience score was significantly lower than the other three learning characteristics and the overall Active Experimentation score was significantly higher than the other three learning characteristics. The Diverger style was shown to be dominant for this group of students. This research also identified an association between learning styles and a number of demographic characteristics.

Previous studies show that Kolb Learning Style Inventory could be utilized for diverse learners with different educational background. In addition, there was also study that investigated both the learning students learning style using Kolb Learning Style Inventory with some interviews. Detail procedures to conduct this study will be presented in methodology section.

\section{Methods}

\subsection{Research design}

In this study, the researchers used both the quantitative and qualitative approaches since the Learning Style Inventory and the interview were the main instruments. The participants were 80 students of the sixth semester, 40 from each department, English 
Education and Computer Science of Mulawarman University, Samarinda. The researchers took both majors due to accessibility to gather the data.

\subsection{Research instruments}

The instruments used in this study were Kolb Learning Style Inventory and interview. The Learning Style Inventory containing 12 items asked students to rank four statements that correspond to the four learning abilities - Concrete Experience, Reflective Observation, Abstract Conceptualization and Active Experimentation. Column A in the Learning Style Inventory represented the Concrete Experience, while B represented the Reflective Observation, column $\mathrm{C}$ represented the Abstract Conceptualization, and D represented the Active Experimentation.

The two total higher scores of the column represent one's learning style. If the student has higher score in Concrete Experimentation rather than Abstract Conceptualization, it means that his or her dominant learning ability in grasping experience process is Concrete Experience, and so the opposite. If the student gets higher score in Reflective Observation rather than Active Experimentation, it indicates that his or her dominant learning ability in transforming experience process is Reflective Observation, and so the opposite. If the student gets higher scores in Concrete Experience and Reflective Observation, meaning that he or she is Diverger learning style. If the student has higher scores in Abstract Conceptualization and Reflective Observation, this shows that he or she is Assimilator learning style. If the student obtains higher scores in Abstract Conceptualization and Active Experimentation, this means that he or she is Converger learning style. If the student achieves higher scores in Concrete Experience and Active Experimentation, meant that he or she is Accommodator learning style.

The Learning Style Inventory has been shown to be both a reliable and valid instrument using the LSI 3.1 total normative group. Reliability has been shown with Cronbach's alpha coefficients ranging between 0.77 and 0.84 , and validity has also been shown through correlation and factor analysis studies (Kolb, 2005)

After analyzing the Learning Style Inventory from students the researcher's selected eight students; four students from each major to be interviewed. These four students represented each learning style; Diverger, Assimilator, Converger, and Accommodator. Semi structure interview was employed to gain comprehensive understanding about the students' learning style.

\subsection{Data collection technique}

Learning Style Inventory firstly translated into Bahasa Indonesia students in order to avoid misunderstanding and tried it out to ten students. The results of the try-out were analyzed and revised in terms of the translation. Next, the translated Learning Style Inventory were distributed to the respondents both from English Department and Computer Department. The responses of the questionnaires were then analyzed. The next step was the interview with the students considering the results of the survey analysis. 


\subsection{Data analysis technique}

The researchers applied simple descriptive statistics to show the mean and frequency of the students' learning style. The mean and frequency statistic could show the distribution of students' learning style and also the dominant learning ability and style. The result of Learning Style Inventory were displayed by charts containing percentages.

For the interview, thematic analysis was implemented using the flow by Miles \& Huberman (1994); data reduction, data display and conclusion drawing and verification.

\section{$3 \quad$ Results}

This section presents the results obtained from the questionnaires and interviews.

\subsection{Questionnaires results}

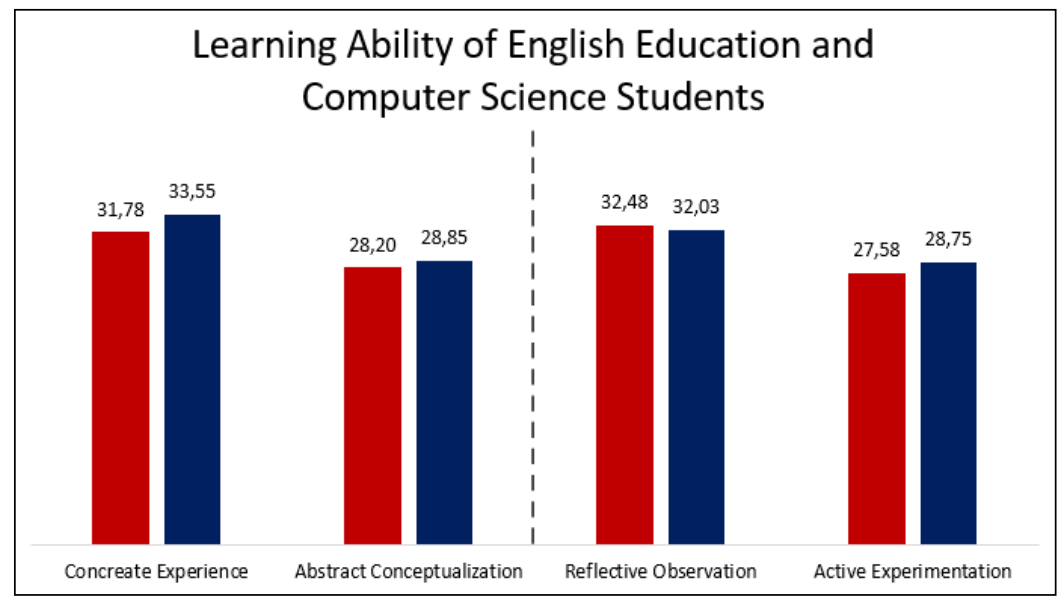

English Education: Blue Computer science: Red

Fig. 2. Learning ability of English Education and Computer Science Students

Figure 2 shows that the results from Learning Style Inventory of English Education and Computer Science students are presented and compared in the form of chart. Generally, the overall results of the students' learning ability both of the English Education and Computer Science students were comparable for each of the learning ability. The left chart (Concrete Experience and Abstract Conceptualization) are students' abilities in grasping experience, while on the right (Reflective Observation and Active Experimentation) are the abilities in transforming experience.

In grasping experience process, both students have more dominant learning ability in Concrete Experience than Abstract Conceptualization ability. This indicates that 
that these students often use their feeling and hunch in study so they prefer learn from their own experience, and are open minded in class activity rather. They less use logic in study and prefer learn from their own general conclusions.

Reflective Observation process is also more dominant than Active Experimentation in transforming experience. This shows that the students more watch situations and have a lot of questions about new things (in mind) in study so that they are quiet and reserved in class activity rather they do and try things out the learning material that they have been studied or are quick in making decision and solving problem.

Therefore, it can be said that the learning ability of the English Education and Computer Science were similar in which both have Concrete Experience ability in grasping experience and Reflective Observation ability in transforming experience process.

\subsection{Learning style}

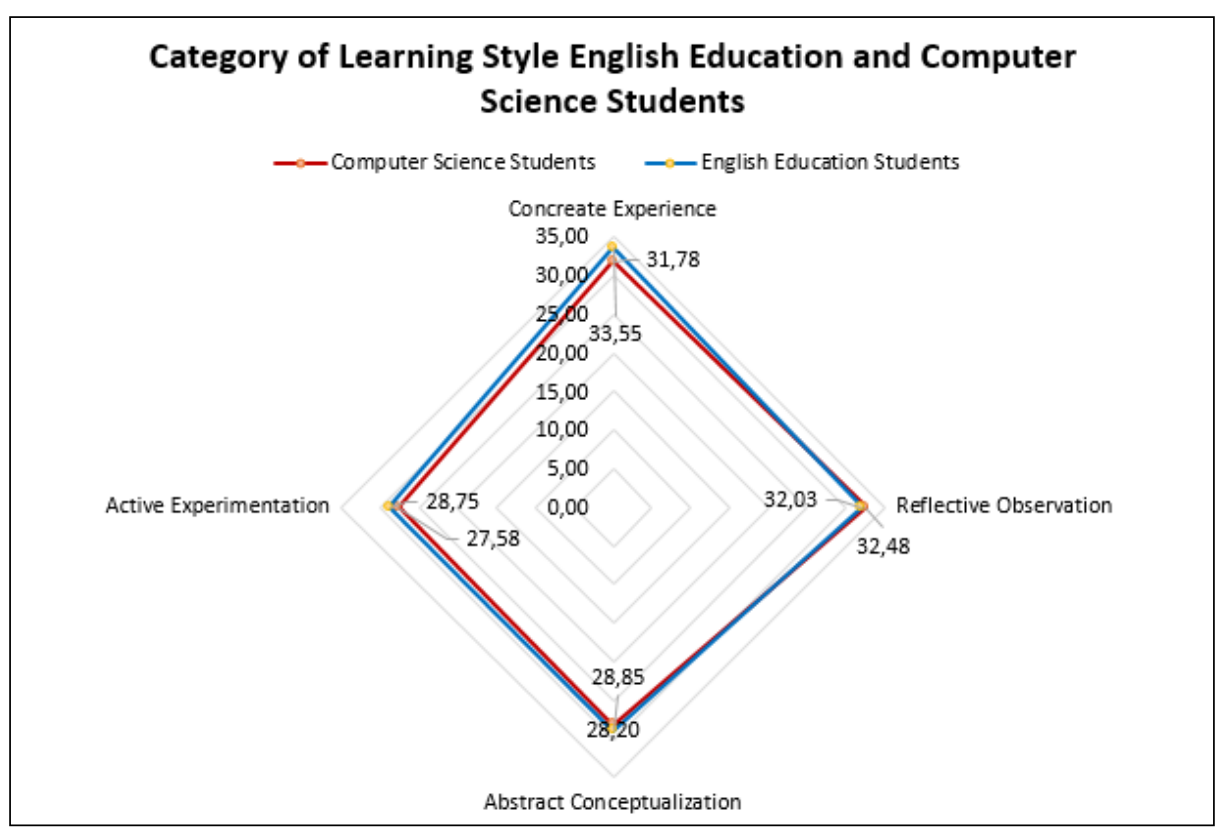

Fig. 3. Learning Style of English Education and Computer Science Students

Figure 3 shows that both students of English Education and Computer Science tend to have more Diverger and Accomodator style in their learning. Diverger style is the combination of Concrete Experience and Reflective Observation ability in which students are interested in people, tend to be imaginative, and emotional. Accomodator is the combination of Active Experimentation and Concrete Experience in which students learn more based on their experience. Details of the learning style distribution of each department can be seen in the Figure 4 and Figure 5. 


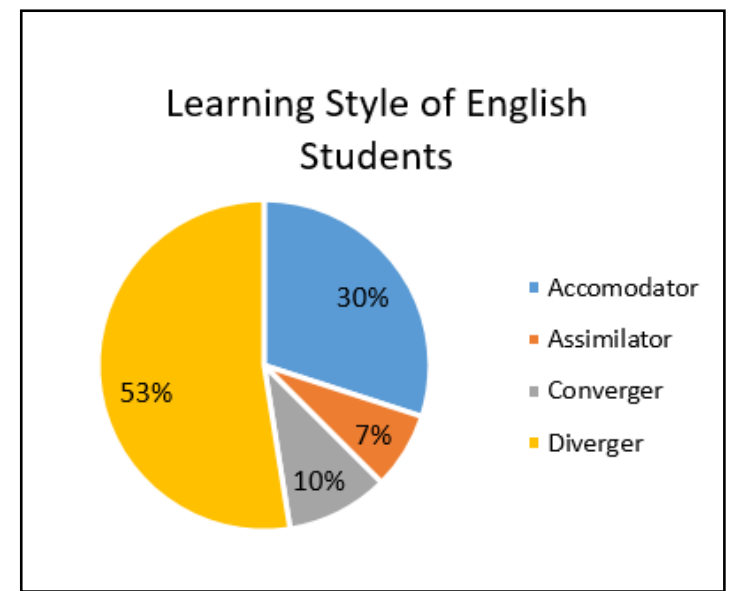

Fig. 4. Learning Style of English Education Students

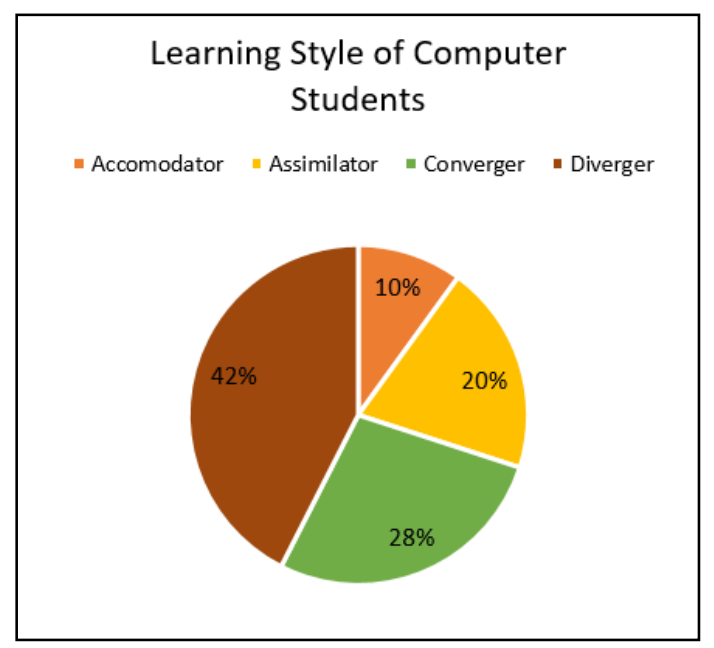

Fig. 5. Learning Style of Computer Education Students

In general, the English and Computer students had dominant learning style of Diverger (Concrete Experience and Reflective Observation) which indicates that the students are interested in people, tend to be imaginative, and emotional. In formal learning situations, these students prefer to work in groups, listening with an open mind to different points of view and receiving personalized feedback. In detail, there were 21 English students (53\%) and 17 Computer students (42\%) were identical in Diverger Style.

The English students were more in Accomodator (Active Experimentation and Concrete Experience) with 12 students (30\%) than the Computer with only four students $(10 \%)$. This implies that the students have the ability to learn from primarily "hands-on" experience. In formal learning situations, these students prefer to work 
with others to get assignments done, to set goals, to do field work, and to test out different approaches to completing a project.

There were more students of Computer Science in Converger style (Abstract Conceptualization and Active Experimentation) with 28\% (11 students) than that of those in English Education with 10\% (four students). Students with this learning style are best at finding practical uses for ideas and theories. In formal learning situations, students with the Converger style prefer to experiment with new ideas, simulations, laboratory assignments, and practical applications.

In addition, there were more students of Computer Science in Assimilator style (Abstract Conceptualization and Reflective Observation) with 20\% (eight students) than of those in English Education with only $7 \%$ (three students). The students are best at understanding a wide range of information and putting it into short, logical form. In formal learning situations, Computer Science students with the Assimilator style prefer reading, being lectured, exploring analytical models, and having time to think things through.

\subsection{Interview results}

The results of interview have indicated similar responses employed by the students of English education and Computer Science. Among eight students, four of English education and four of Computer Science, six students would think first in responding a problem or in learning and two of English students tried to used prediction as stated "The most dominant is using my hunch. If I had an assignment, mostly I guessed what was the purpose of it." (ES-1). So, the students predicted what the objective of the assignment. The students indicated that they had more Abstract Conceptualization than Concrete Experience.

When the students were asked how they drew a conclusion, half of students form each department indicated that they could make a conclusion by their own and considering other opinions or sources as one's response "Considering others' opinions, because if we do not have a knowledge in one thing, the others can share it." (CS-2). This showed that these students were not individualistic people because they accepted others' ideas. The students used both Abstract Conceptualization and Abstract Conceptualization equally.

Six students indicated that they would understand more and have less difficulties if the lesson or knowledge was something they had experienced before while two Computer students preferred making sense of the new knowledge. One of them informed "Something that I have ever seen and heard before. That is more understandable than something I have never known" (CS-4). It could indicate that these students feel this kind of learning material which based on their own experience was easier to understand. This means that the students employed more ability Abstract Conceptualization than Concrete Experience.

In responding the question about how the students react towards new knowledge, the English students would wonder about it by asking questions. This means the students applied more Reflective Observation than Active Experimentation. However, two students of Computer Science would try to apply it as one of them reported "I 
will try and do it to make sure it works and is acceptable" (CS-4). It implied that the students prefer to do practical tasks. They like to implement as soon as possible the learning material they had studied so that the students applied more Active Experimentation than Reflective Observation.

All students needed time to think in order to make selection however the Computer students would think and immediate decision. One told that "Quick and firm. Because if we can make a choice quickly, it will be better." (CS-2). In addition, they also indicated that they tended to be quite in their learning as one English student reported "Maybe because I am a quiet person, so I tend to be calm." (ES-2). Other Computer student mentioned that "Having good attention, analysing and accepting things I can learn" (CS-3). Students have more Reflective Observation than Active experimentation.

\section{Discussion and Conclusion}

The preferred learning style of English Education are Diverger, Accomodator, Converger, and Assimilator while the Computer Science students have preference more on Diverger, Converger, Assimilator, and Accomodator respectively. Further detail, Diverger and Accomodator are prevailing for English Education students. Diverger is the major learning style of Computer Science students followed by Converger and Assimilator. These findings supported previous study by D'Amore (2012) who found that the first-year Bachelor of Nursing, Bachelor of Midwifery and Bachelor of Arts students employed Diverger style. In addition, the results were in line with the study by Parnrod, Darasawang and Singhasiri (2014) who found that Diverger was the most dominant style employed by engineering students

Generally, the overall results of the students' learning ability both of the English Education and Computer Science students were comparable for each of the learning ability. In grasping experience process, both students have more dominant learning ability in Concrete Experience than Abstract Conceptualization ability. Reflective Observation process is also more dominant than Active Experimentation in transforming experience. Therefore, it can be said that the learning ability of the English Education and Computer Science were similar in which both have Concrete Experience ability in grasping experience and Reflective Observation ability in transforming experience process. This finding does not support the study by D'Amore (2012) who found that Active Experimentation score was significantly higher than the other three learning characteristics.

In learning style, students of English Education and Computer Science tend to have more Diverger style in their learning. The English students were more in Accomodator (Active Experimentation and Concrete Experience) with 12 students (30\%) than the Computer with only four students $(10 \%)$ as the least style applied, while students of Computer Science in Converger style (Abstract Conceptualization and Active Experimentation) with 28\% (11 students) than that of those in English Education with $10 \%$ (four students). 
The interview results indicated that the students had more Abstract Conceptualization than Concrete Experience in responding a problem or in learning using more thinking. In addition, the students more understood the lesson if they have had before. In drawing a conclusion, the students also consider others' opinion besides their own meaning that they employed both Abstract Conceptualization than Concrete Experience. Furthermore, in responding the question about how the students react towards new knowledge, in making selection, and their behavior while learning, generally the students employed more Reflective Observation than Active Experimentation. To be more specific, all English students had Reflective Observation, however, the Computer students had both the Reflective Observation and Active Experimentation.

Therefore, it could be concluded that in general the students of English Education and Computer Science have similar learning style and ability. However, in more specific, the English students tend to be more Diverger and Accomodator while Computer students employed more Diverger and Converger characteristics. This implied that the English students were likely to observe, do and feel while the Computer students had more mixed style; feel, observe, and think and do.

\section{Acknowledgement}

The authors would like to acknowledge the support to this project by the IDB Project Grant, Universitas Mulawarman, Samarinda, Indonesia for providing financial support.

\section{References}

[1] Alzain, A. M., Clark, S., Jwaid, A., \& Ireson, G. (2018). Adaptive Education based on Learning Styles: Are Learning Style Instruments Precise Enough? International Journal of Emerging Technologies in Learning (IJET), 13(9), 41-52. https://doi.org/https://doi.org/10.39 91/ijet.v13i09.8554

[2] Ayidin, B. (2016). Examination of the relationship between eight grade students learning styles and attitudes towards mathematics. Journal of Education and Training Studies 4(2), 124-131 https://doi.org/10.11114/jets.v4i2.1162

[3] Barmeyer, C. I., 2004. Learning styles and their impact on cross-cultural training: An international comparison in France, Germany and Quebec. International Journal of Intercultural Relations, 28, 577-594. https://doi.org/10.1016/j.ijintrel.2005.01.011

[4] Burns, A. \& Danyluk, P. (2017). Applying Kolb's model to a nontraditional preservice teaching practicum. Journal of Experiential Education, 40(3), 249-263, doi: 10.1177/1053825917696832 https://doi.org/10.1177/1053825917696832

[5] Biadabadi, F.S., 2010. Learning Style Preferences by Iranian EFL Freshman University Students. Procedia Social and Behavioral Sciences 7(C) 219-226 https://doi.org/10.1 016/j.sbspro.2010.10.031

[6] Conti, G.J. (2004). Identifying your teaching style. In M.W. Galbraith (Ed.), Adult learning methods: A guide for effective instruction (3rd ed., pp.7591). FL: Krieger Publishing Company. 
[7] Cornett, C., 1983. What you should know about teaching and learning styles. Bloomington, IN: Phi Delta Kappa.

[8] Dunn, R. (1990). Understanding the Dunn and Dunn learning styles model and the need for individual diagnosis and prescription. Reading, Writing, and Learning Disabilities, 6, 223247.https://doi.org/10.1080/0748763900060303

[9] D'Amore, A., 2012. Learning styles of first-year undergraduate nursing and midwifery students: A cross-sectional survey utilizing the Kolb Learning Style Inventory. Nurse Education Today, 32, 506-515 https://doi.org/10.1016/i.nedt.2011.08.001

[10] Eskişehir, M.O. \& Bouvet, E. (2016). Investigating reading comprehension and learning styles in relation to reading strategies in L2. Reading in a Foreign Language (28), 20-42.

[11] Felder, R. M., \& Silverman, L. K. (1988). Learning and teaching styles in engineering education. Engineering Education, 78(7), 674-681.

[12] Gardner, H. (1985). Frames of mind: The theory of multiple intelligences. New York: Basic Books.

[13] Parnrod, U., Darasawang, P., Singhasiri, W. (2014) Styles, strategies \& tasks: Are they related? PASSA, 27, 1-21.

[14] Sato, T. \& Laughlin, D.D. (2018). Integrating Kolb's experiential learning theory into a sport psychology classroom using a golf putting activity. Journal of Sport Psychology in Action, 9(1), 51-62 https://doi.org/10.1080/21520704.2017.1325807

[15] Slavin, R. E. (2000). Educational psychology: Theory and practice. Boston: Allyn \& Bacon.

[16] Kaplan, E.J. \& Kies, D.A. (1995). Teaching and learning styles: Which came first? Journal of Instructional Psychology, 22(1), 29-33.

[17] Kolb, D. A., 1984. Experiential Learning: Experience as the Source of Learning and Development. Englewood Cliffs, NJ: Prentice Hall.

[18] Kolb, A. Y., Kolb, D. A., 2005. The Kolb Learning Style Inventory - Version 3.12005 Technical Specifications. Hay Group Holdings, Inc., Boston.

[19] Malcik, M., \& Miklosikova, M. (2017). Learning Styles of Students as a Factor Affecting Pedagogical Activities of a University Teacher. International Journal of Emerging Technologies in Learning (IJET), 12(2), 210-218. https://doi.org/10.3991/ijet.v12i02.6277

[20] Miles, M. B., \& Huberman, A. M. (1994). Qualitative data analysis: An expanded sourcebook (2nd Ed.). Thousand Oaks, CA: Sage.

[21] Mouzouri, H. (2016). The Relationships between Students' Perceived Learning Styles and the Community of Inquiry Presences in a Graduate Online Course. International Journal of Emerging Technologies in Learning (IJET), 11(4), 40-47. https://doi.org/10.3 991/ijet.v11i04.5312

[22] Oxford, R.L., 2003. Language learning styles and strategies: An overview. Learning Styles \& Strategies/Oxford, GALA. https://doi.org/10.1515/iral.2003.012

[23] Partridge, R. (1983). Learning styles: A review of selected models. Journal of Nursing Education, 22(6), 243-248. https://doi.org/10.3928/0148-4834-19830601-06

[24] Vural, L. (2016). The relation between prospective teachers' and their parents' learning styles. Educational Research and Reviews, 11(15), 1415-1423 https://doi.org/10.5897/ERR2016.2637

[25] Woolfolk, A. (1998). Educational Psychology. Boston: Allyn \& Bacon.

\section{$7 \quad$ Authors}

Dyah Sunggingwati is a lecturer and has been teaching at English Department, Faculty of Teacher Training and Education, Mulawarman University, Indonesia, since 2001. She obtained a Ph.D. degree in Education from the University of Queensland, 
Australia. She is the coordinator of Master Program of English Education in her university. Her current research interest is reading comprehension in a foreign language, ELT, and professional development. Email id:sunggingwati@gmail.com

Haviluddin is a lecturer at Faculty of Computer Science and Information Technology (CSIT), Mulawarman University, Indonesia, since 2002. He completed his Ph.D. in Computer Science from Universiti Malaysia Sabah, Malaysia in 2016. He is the coordinator of publication and intellectual property rights of Research Institute and Community Service of Mulawarman University. His research interest is in artificial intelligent area. Email id: haviluddin@unmul.ac.id

Article submitted 2018-12-12. Resubmitted 2019-01-28. Final acceptance 2019-01-29. Final version published as submitted by the authors. 